MH Egészségügyi Központ Sziv, Ér-és Mellkassebészeti Osztály

\title{
Katonaorvosi tapasztalatok az innováció szolgálatában
}

\author{
Dr. Pellek Sándor orvos ezredes, PhD
}

Kulcsszavak: katonai orvoslás, innováció, mellkas, negatív nyomásterápia (NPWT)

\begin{abstract}
Az orvostudomány folyamatos fejlödése az egyes szakterületek - a tudás növekedése miatt - osztódnak és kisebb specialitások jelennek meg. A katonai orvoslás is jelentős hozzáadott értéket képvisel a fejlődésben. A hadmüveleti területen szerzett tapasztalatok, innovációk és azok alkalmazása békeidőben lökést adhatnak a modern orvoslásnak. A szerző jelen cikkében bemutatja az afganisztáni területen szerzett tapasztalatait, a szeptikus mellüregi gennyesedések gyógykezelésében és kitér az eredmények békeidejü alkalmazására.
\end{abstract}

Történeti alapok - szemelvények a korai szakaszból

Augustus császár (Kr.e. 63-Kr.u. 14) az általa végrehajtott hadmüveletek során öszszegyüjtött tapasztalatokból számos, a következő műveletekben hasznosítható ereményeket rendszerezte. Megállapította, hogy a hadseregének erejét és morálját meghatározza az egészségügyi ellátás minősége, gyógyulás reménye. Az egészségügyi ellátás nélkülözhetetlenségét felismerve létrehozta a történelem első hivatásos katonai egészségügyi szolgálatát. A szolgálat tagjai jártasak voltak a sebek, fertőzések kezelésében. Az általuk - a napi gyakorlatban - használt eljárások és egészségügyi tevékenységük egészen a XIX. századig vezető szellemiségünek minősíthető. A magyar katonaorvosi tapasztalatokat a világháborúk közötti időkben dokumentálták, amelyek számunkra értékes infor- mációt tartalmaznak a sebkezelés folyamatos változásainak megismerésében.

Az utóbbi évtizedek gyökeres változást hoztak a végtagok lövéses töréseinek kezelésében.

Az extrafokális rögzítés, intrafokális antibiózis és a lágyrész management a negatív nyomásterápia megjelenésével új alapokra helyeződött. Ezen eredmények egy része felhasználható és jó szolgálatot tesz a szeptikus mellkasi kórképek kezelésében is.

\section{Innovatív sebészeti tapasztalatok hadmüveleti területen, Afganisztánban}

A magyar katonai sebészet a krízisövezetekben nagy tapasztalatokat és szakmai elismertséget ért el. A folyamat már a koreai háborútól visszakövethető. A jelentős szakmai elődök műveleti sebészeti ta- 
pasztalatai elfogadásra és eredményesen felhasználásra kerültek, a betegek gyógyítása érdekében. A szerző katonaorvosi innovációs tapasztalatait Afganisztánban szerezte 2003-tól, a kabuli ROLE III. Bundeswehr tábori kórházban. A súlyos sérülések során keletkezett testüreg, csont és lágyrész sérüléseket egy, a szerző számára új technológiával kezdték ellátni. A módszer lényege a nagy sebek (testüregek) nyitva hagyása és a külvilágtól történő izolálása egy olyan speciális szivacsrendszerrel, amely vákuum közbeiktatásával a test váladékait elvezeti és biztosítja a gyógyuláshoz szükséges biológiai feltételeket. A seb tisztul, a vérellátás javul, amely a test általános kondíciójának változását pozitívan befolyásolja. Az első eset egy gyermek nyílt bokatörésének ellátása volt, amelyet ezzel a speciális negatív nyomásterápiás rendszerrel sikerült megoldani (1., 2.ábra). A NPWT - Negative Pressure Wound Treatment mára széleskörben, csaknem minden sebészeti szakma által használt hatékony ellátási technika.

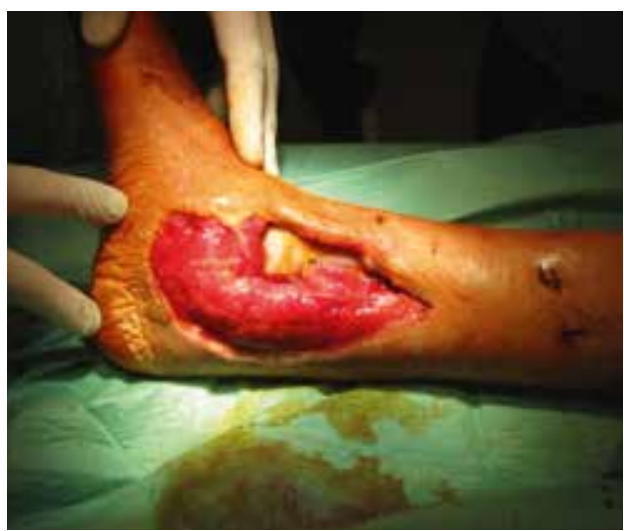

1. ábra. Nyilt bokatörés, nagy lágyrészhiánnyal (A szerző afganisztáni saját anyaga)

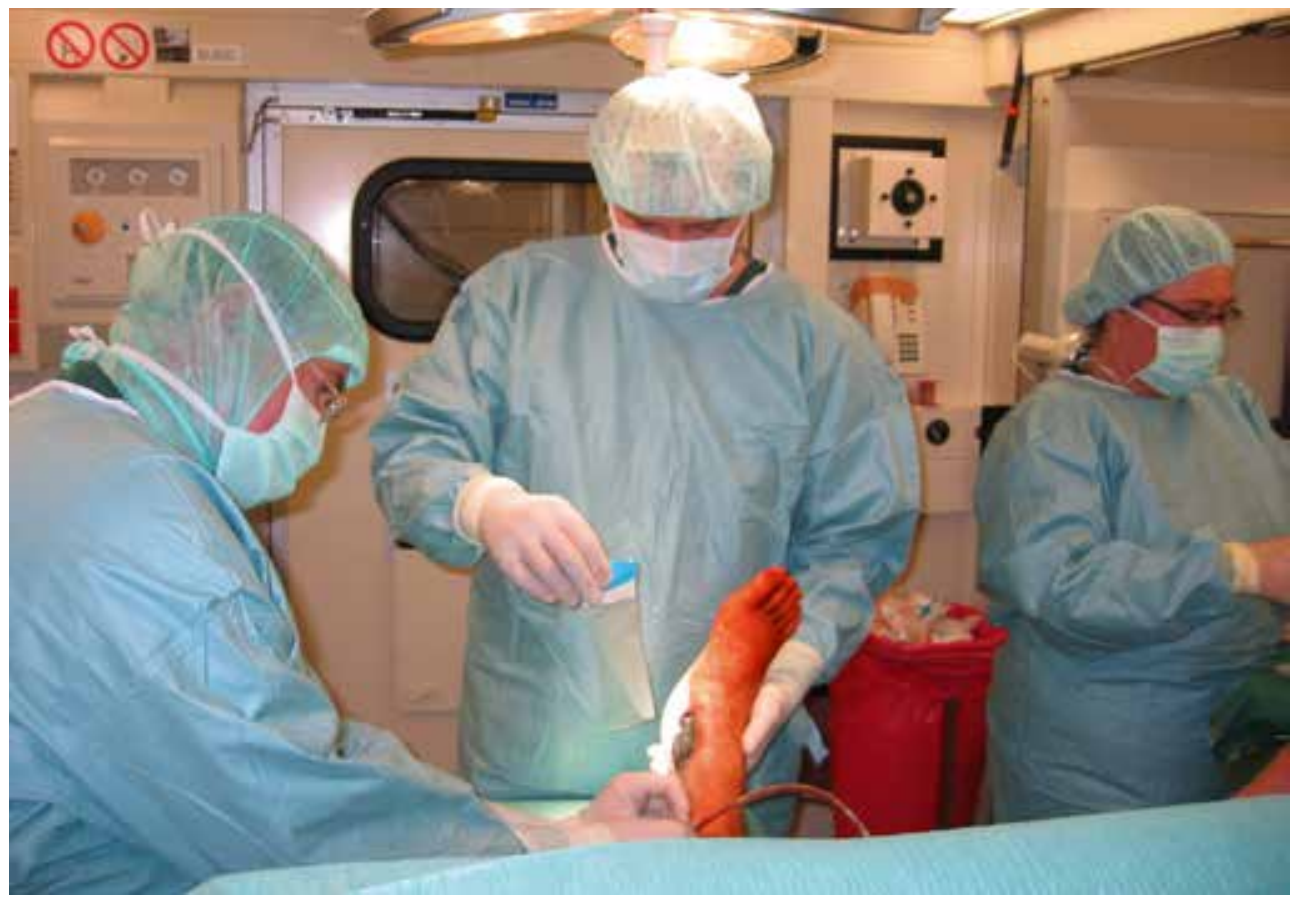

2. ábra. Nyilt bokatörés stabilizációja után, a lágyrészhiány fedése vákuumszivacsos (NPWT) rendszerrel. Multinacionális (francia-magyar-német) sebészi team 


\section{Patofiziológiai változások mellkasi sérülések esetén}

A mellkasi sérülések nem a mellkas egyes anatómiai egységének, hanem teljes funkcionális képességének változásait foglalják magukban. Mellkasi sérülések indukálta patofiziológiás változások során jelentős következményekkel járó lépcsőzetes folyamat alakul ki. Ezek a fájdalom, a tüdőzúzódás, a légzőfelszín csökkenése, a légzési statika károsodása és a légúti akadályok. A restriktív inszufficiencia ventillációs zavarban, alveoláris hypoventillációban, kisvérköri keringés megváltozásában, a bal szívfél elégtelenségében nyilvánulhat meg. Obstruktív inszufficiencia esetén respiratórikus acidózis, shunt-keringés, pulmonális hipertenzió és ezek eredményeképpen akut szívelégtelenség alakulhat ki. A pangó légúti váladék mikrobiológiai vizsgálata 25-féle kórokozót tartalmazhat, amelyek 90\%-ban okai lehetnek a kialakuló szepszisnek. Infekció, bakterémia, szepszis, SIRS (systemic inflammatory response syndrome), többszervi müködési elégtelenség (MOF - Multiple Organ Failure) a patofiziológiai folyamat progresszív kimenetele.

\section{A szepszis megelözésének jelentősége}

A szepszis a medicina fejlődése ellenére is aktuális kutatási terület. A szepszis a fertőzések potenciálisan életveszélyes következménye. A kialakuló gyulladásos változások, egy kaszkádot indítanak el a szervezetben, amelyek az életfontosságú szervek müködési elégtelenségét okozhatják. Abban az esetben, ha a szepszis szeptikus sokk állapotába megy át, drámai vérnyomásesés jöhet létre, amely a beteg számára halálos kimenetelü is lehet.
A XXI. századi medicina folyamatos fejlődése ellenére a szepszis felismerése és kezelése állandó kihívást jelent a gyakorló orvosok számára. A szepszis hazai és hadmüveleti környezetben gyakran későn kerül felismerésre. A betegség halálozási aránya rendkívül magas.

A betegség korai felismerése, kezdeti stádiumban indított kezelése esetén várható csak jó életminőséget biztosító gyógyulás. A kezelés jelentős gyógyszer és humánerőforrás igénye, valamint a kórházban eltöltött hosszú idő miatt, elöre nem látható magas költségeket eredményeznek. Hadműveleti környezetben elöre kidolgozott és alkalmazott protokollok használata mellett az egészségügyi veszteség minimalizálható. A szepszis kezdeti stádiumának észlelése békében, hadmüveleti szituációkban, és különleges helyetekben egyaránt meghatározó tényező a beteg túlélése szempontjából.

\section{Az empyema thoracis általános etiológiai tényezői}

\begin{tabular}{|l|c|}
\hline $\begin{array}{l}\text { A tüdő primer betegsége } \\
\text { (pneumonia, tüdőtályog, } \\
\text { tüdőtumor) }\end{array}$ & $60 \%$ \\
\hline $\begin{array}{l}\text { Mellkasi mütétek (tüdőrezekció, } \\
\text { nyelöcsőrezekció) }\end{array}$ & $15 \%$ \\
\hline $\begin{array}{l}\text { Traumás és spontás légmell- } \\
\text { ptx, HTX, HPTX }\end{array}$ & $10 \%$ \\
\hline $\begin{array}{l}\text { Szeptikus tüdőembólia } \\
\text { (tromboflebitis, általános } \\
\text { sebészeti mütétek, stb. }\end{array}$ & $10 \%$ \\
\hline Szubfrenikus tályog & $3 \%$ \\
\hline
\end{tabular}

A mellkasi sérülések és mütétek utáni mellüregi gennyedést leggyakrabban Gram-pozitív gennykeltők, Gram-negatív baktériumok, Mycobacterium tuberculosa, anaerob baktériumok, hosszabb 
klinikai esetben vegyes baktérium-flóra okozzák. A hosszú ideig hospitalizált betegeknél kialakult mellüregi gennyedések eseteiben a nozokomiális infekció is szerepet játszik, ezek leggyakrabban az MRSA, Pseudomonas aeruginosa, Staphylococcus aureus, Klebsiella és a Proteus baktériumok.

\section{Az empyema thoracis stádium orientált kezelési módszerei}

A mellüregi gennyedések csak abban az esetben kezelhetök eredményesen, ha a tüdő expanzióra (tágulásra) képes és kitölti a mellüreg teljes térfogatát, ellenkező esetben mindenképpen sebészi intervenció a járható út.

Stádium 1: A mellüregben fellelhető folyadék eltávolítása a mellüreg csövezésével, kiegészítő szívókezeléssel és a csövön keresztül alkalmazott antiszeptikus öblítéssel. A mellüregi folyadékból vett mikrobiológiai mintavétel alapján célzott antibiotikus kiegészítő kezelés lehet hatékony.

Stádium 2: Abban az esetben, ha mellüregi folyadékban megjelent a fibrin, akkor ennek a fibrino-purulens komponensnek az oldása megkísérelhető, pl.: sztreptokinázéval. Ezzel párhuzamosan a mellüreg öblítö-szívókezelését tovább kell folytatni, kiegészitő, célzott antibiotikus terápiával.

Stádium 3: Az elhúzódó, néha eredménytelen kezelések során a mellüregben és a tüdő felszínein zsugorító kallusz alakulhat ki, amelynek kezelése már komplex beavatkozást igényel. Az empyema üreg megszüntetése gyakran, csak „open window” kezeléssel - a mellkasfal fenesztrációjával - oldható meg. Ezekben a súlyos esetekben a beteg gyógyulását jelentősen segítheti az NPWT kezelés.

\section{A mellüregi gennyedés terápiájának változása}

A mellkasi üregre lokalizálódott genynyedéses folyamat minimál sebészeti módszerekkel nem kezelhető eredményesen. Konkrét klinikai példákon keresztül szemléltethető a mellkas tályogrendszerének tervezhető kezelése, amelyet a mellkas falán készített ablakon keresztül végeznek el. A mellkasi üreget az antiszeptikus öblítéseket követően a mellüregbe helyezett szivacs technikával és negatív nyomásterápiás sebészeti eszközzel (NPWT) zárják. A nyílt mellkasi kezeléssel és a negatív nyomásterápia alkalmazásával a tüdő képes a teljes kitágulásra, folyadék és a levegő zárványok nem maradnak a mellüregben, így a szeptikus fókusz kiterelhető a mellkasi ablakon át. A szabad üreg eltávolításával és célzott antibiotikum-terápiával a szeptikus kórkép teljesen meggyógyulhat. A mellkasi üregben végzett negatív nyomáskezelés egy olyan eljárás, amely biztonságosan és eredményesen használható. A mellkasi üregbe helyezett szivacsot rendszeresen cserélni kell. A mellkasfalon képzett ablak és a negatív nyomásterápia együttes használatával a kezelés folyamata tervezhető. Az elsődleges mütéti beavatkozást követően a behelyezett szivacs méretének fokozatos csökkentését végezzük el, a szabad mellkasi üreg fokozatosan szükül, majd lassan eltünik. A mellkasfal ablakát izomréteggel és bőrrel tudjuk befedni, miután a mellüreg steril állapotba került. A negatív nyomásterápia sikeresen alkalmazható a mellüreg gennyedéses folyamataiban - még a kezdetben, kezelésre nem reagáló esetekben is. A jól kidolgozott terápiás protokoll (sebészet és antibiotikum) a kezelési időt jelentősen csökkenti (3. ábra). 


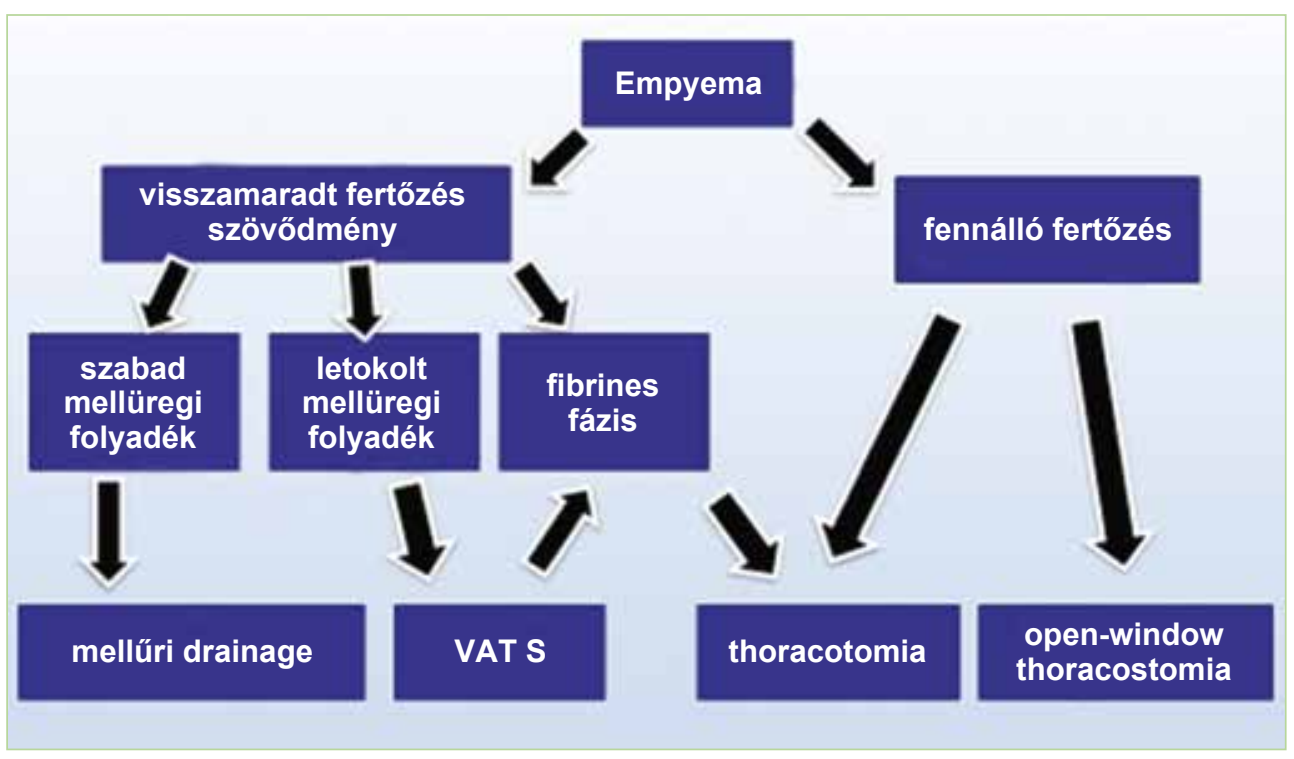

3. ábra. A mellüreg gennyedéses folyamatainak stádium orientált ellátási javaslata (A szerző saját szerkesztése és ajánlása)

\section{$A z$ „open window” thoracostomia}

Bordatörések, a mellüreg bevérzése miatt, a szabad folyadék felülfertőződése súlyos szeptikus állapotot hozhat létre. Abban az esetben, ha a megkezdett mellkasi csövezés, antiszeptikus öblítések eredménytelenek, a mellkasi CT-vizsgálat gyakran a folyamat rekeszessé történő átalakulását igazolja. Ebben a klinikai stádiumban minimál sebészi módszerrel eredmény nem érhető el. „Open window" thoracostomia alkalmazásával viszont a kezelés effektíven végezhető. A mellkas és a tályogüreg legmélyebb pontján a VIII. és a IX. bordák részleges eltávolítását végezzük el, a mellhártyát a bőrrel összevarrjuk, mellkasfali ablakot alakítunk ki. A munkacsatornán keresztül történik a tályog és a tályogfal eltávolítása, a dekortikáció. Antiszeptikus öblítések után, a „mellkasfali ablakon” keresztül behelyezett szivacsos módszerrel, negatív nyomásterápiás eszközzel zsugorítjuk az üreget, a tüdő tágulási képességének megfelelően. A nyitott mellkasi kezeléssel, negatív nyomásterápia felhasználásával a tüdő teljes tágulásra képes. A visszamaradó folyadékterek, levegőzárványok eltünnek, így a szeptikus góc a mellkasfali ablak felé terelhető. A szabad üreg megszüntetésével és a célzott antibiotikus kezeléssel a szeptikus folyamat teljes mértékben szanálható. A mellüreg gennyedéses folyamataiban a negatív nyomásterápia eredményesen alkalmazható - a kezdetben terápia rezisztens esetekben is. A jól kialakított protokollal, a célzott antibiotikus kezelés tervezhető ápolási időt biztosít (4., 5. ábra).

\section{Módszertani ajánlás a hadmúveleti terüileten szerzett tapasztalatok alapján}

NPWT kezelés felhasználásával, kiegészítő antibiotikus kezeléssel a mellüregi szeptikus folyamatok teljes mértékben gyógyíthatók. 


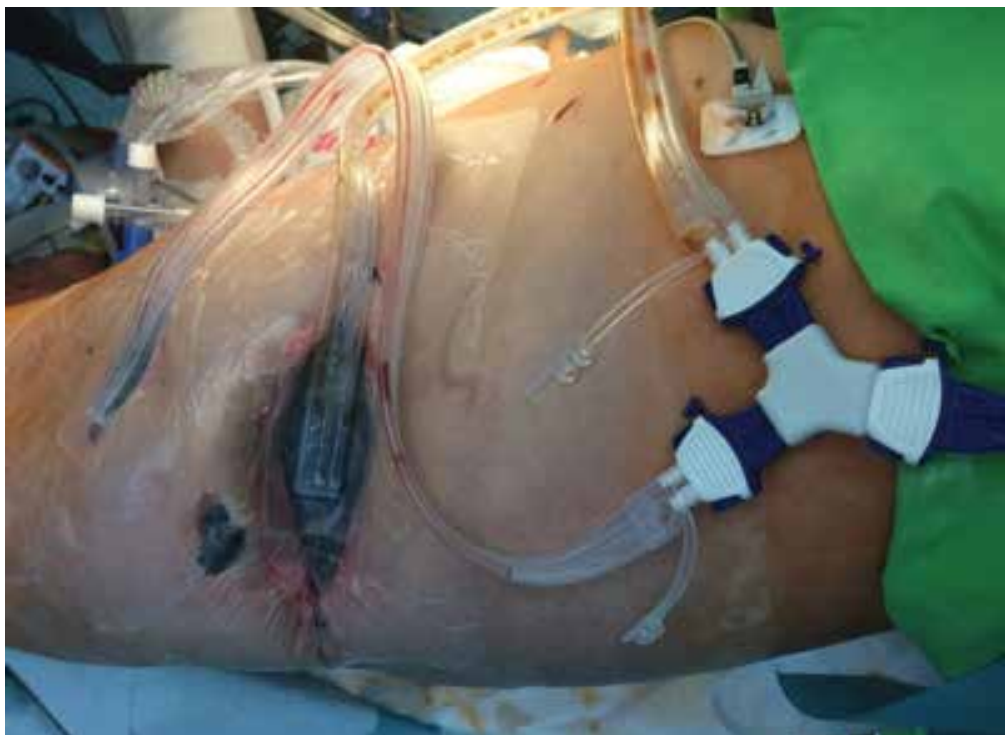

4. ábra. Megnyitott mellkas jobb oldalon, a mellüreg ideiglenes zárása NPWT módszerrel (A szerzö saját MH EK anyaga)

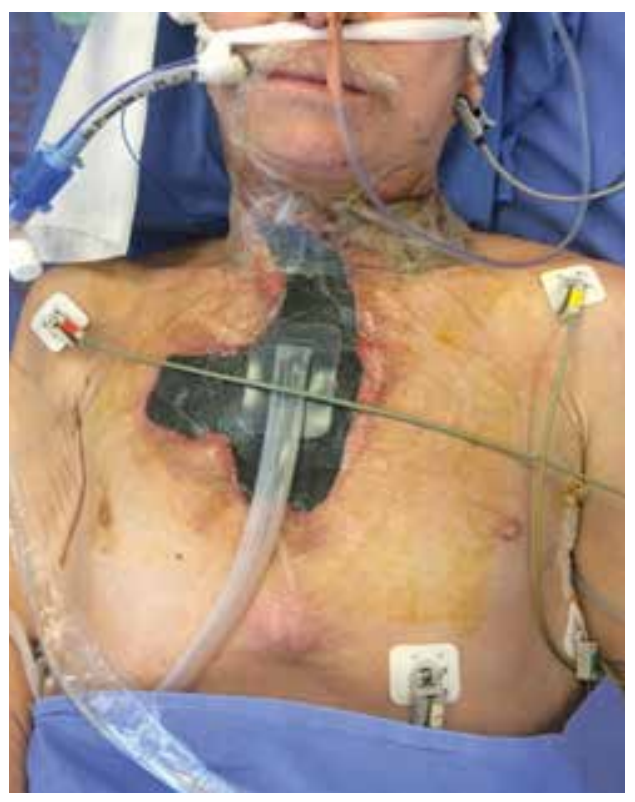

5. ábra. A mellkas-nyak határ gennyedéses folyamata az elülsö mellkasfali szövetek lágyrész elhalását okozta. Az elhalt szövetek eltávolitása után NPWT-szivacs ideiglenes beültetés és sebkezelés történt

(A szerző saját MH EK anyaga)
A kezelés kritériumai:

1. a szabad üreg megszüntetése,

2. célzott antibiotikus kezelés (mikrobiológiai vizsgálat alapján).

A mellüregben végzett negatív nyomásterápia biztonságosan alkalmazható eljárás. A mellüregbe helyezett szivacs, folyamatos cserére szorul. A mellkasfali ablak kombinált alkalmazásával a szivacsokat háromnaponta kell cserélni. Az első mütét után („open window” thoracostomia) tervezetten indokolt a mellüreg revíziója és csökkenő méretű szivacs cseréje. Ennek ritmusa a tüdő expanziós képessége visszatérésének a függvénye.

A NPWT-kezelést akkor kell abbahagyni, amikor a szabad mellkasi üreg megszünik. A kezelést akkor tartjuk eredményesnek, illetve befejezettnek, ha a mellüregi „steril állapot” elérése után (két negatív tenyésztési eredmény) izomlebennyel zártuk a mellkasfali ablakot, majd a bört. 


\section{A Magyar Honvédség Egészségügyi Központ szerepe az eljárás szervezeti alapjainak lefektetésében}

Az elmúlt évtizedekben, Koreától Afganisztánig végrehajtott hadműveletekben magyar katonaorvosok a patofiziológiai folyamatok megértésében és a tapasztalatok gyakorlati felhasználásában jelentős elörelépést tudhatnak magukénak, tudásukat mindig, feltétel nélkül osztották meg. A negatív nyomásterápiával végzett sebkezelések tapasztalatszerzésében is a Magyar Honvédség Sebészeti Csoportjának úttörő szerepe van hazánkban. Támogatásukkal 2016-ban megalakult a „Negatív Nyomásterápiával a Sebgyógyulásért Egyesület”.

A megalakításban aktív szerepet vállaltak a katonaorvosok:

Dr. Bakity Boldizsár (1952-2017) orvos ezredes, I. sz. Sebészet osztályvezető föorvos,

Dr. Debreczeni Béla $\mathrm{PhD}$, főorvos, plasztikai sebész,

Dr. Pellek Sándor PhD, orvos alezredes, traumatológus, a Mellkassebészeti részleg vezetője.

Dr. Zsiros Lajos $\mathrm{PhD}$, ny. orvos dandártábornok, Traumatológiai osztályvezető főorvos.

\section{A tapasztalatok megosztása hazai és nemzetközi tudástérben}

A tapasztalatok és ismeretek megosztása kulcsfontosságú kérdés. Fontos az ismeretek eljuttatása a hazai és a külföldi kollégáknak, de ennél is fontosabb az egyetemi hallgatók, rezidensek, továbbá szakorvosjelöltek tudásfejlesztése. A „Negatív Nyomásterápiával a Sebgyógyulásért Egyesület", tagjainak szakmai tapasztalatait összegyüjtve, rendszerezve könyvet jelentetett meg. A könyv szerkesztését a Ma- gyar Honvédség Egészségügyi Központ és a Debreceni Egyetem együttmüködésével valósítottuk meg.

A kiadvány hazai felhasználásra magyar nyelven 2017-ben jelent meg „Elméleti ismeretek és gyakorlati alkalmazás. Negatív Nyomásterápia" (ISBN: 9786150010007) címmel.

A nemzetközi piacra, angol nyelven, 2019-ben került forgalomba "Negative Pressure Wound Therapy" (ISBN: 9876150050898) (6. ábra).

\section{Mai tudásunk szerint, hol alkalmazható a negatív nyomásterápia?}

Az elmúlt évek tapasztalatai alapján a következő szakterületeken alkalmazták eredményesen a negatív nyomásterápiát: sebészet, szívsebészet, mellkas sebészet, urológia, fej-nyak sebészet, traumatológia, ortopédia, gyermek sebészet, bőrgyógyászat, érsebészet, plasztikai sebészet. Tekintettel arra, hogy egy prémium minőségü, az innovációt szabadon magában hordozó technológiáról van szó, várható a közeljövőben a szakterületek kiterjesztése és interdiszciplináris együttműködésben történő használata.

\section{Irodalom}

[1] Pellek S.: Katonaorvosi tapasztalatok az innovatív technológia - NPWT - szolgálatában. Sport és Egészség a Honvédelemért Konferencia, 2019. április 25-26., MKB Bank, Budapest

[2] Pellek S.: Sürgősségi betegellátás egyes kérdései a NATO multinacionális egészségügyi biztosítás rendszerében. $\mathrm{PhD}$ értekezés, 2012, NKE, Hadtudományi Doktori Iskola.

DOI: 10.17625/NKE.2013.010.

[3] Pellek S.: A katonaorvosi képzés kérdései a NATO szövetségi rendszerében. Katonai Logisztika, 2016 különszám 424-436. 

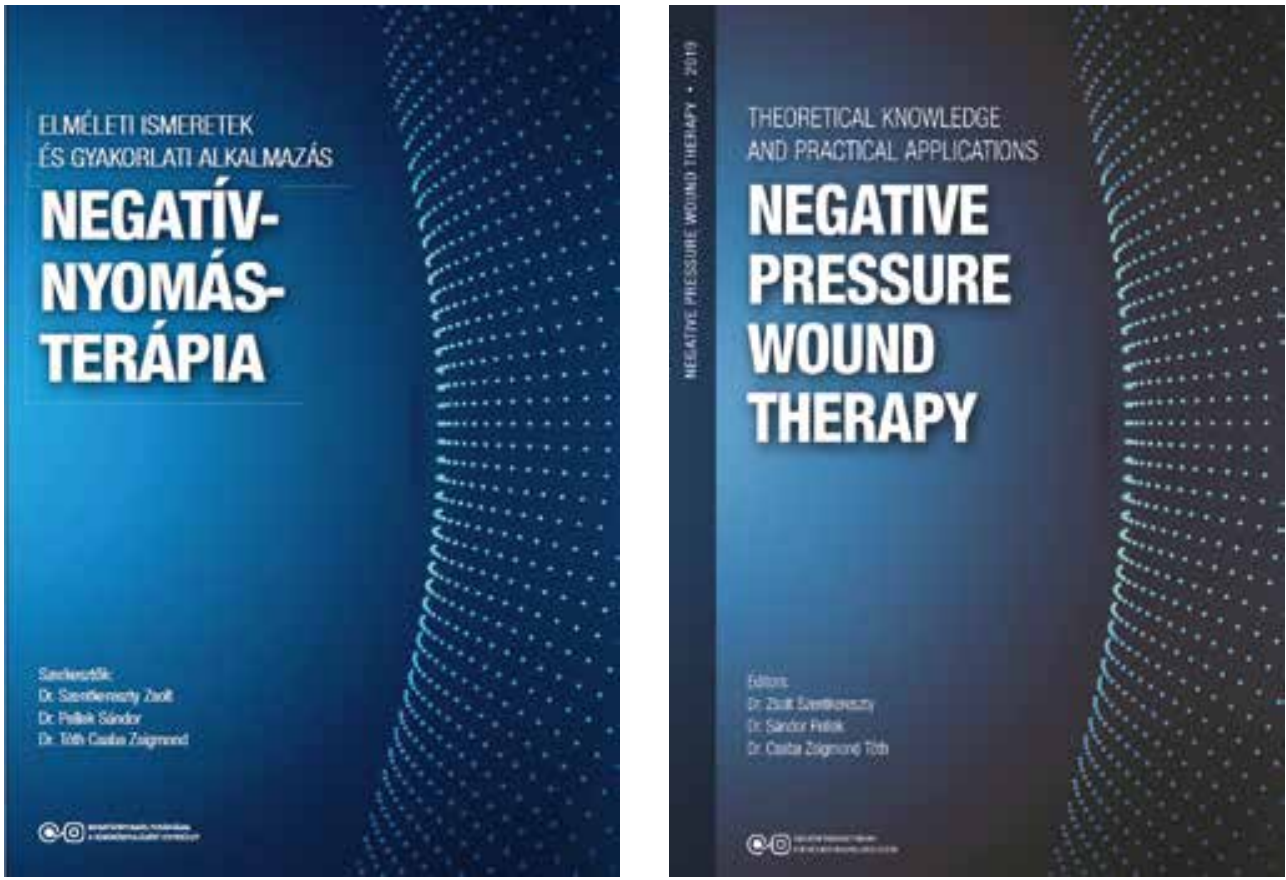

6. ábra. Magyar nyelven, 2017-ben, angol nyelven 2019-ben megjelent szakkönyvek

[4] Dzsinich Cs., Zsíros L., Vallus G. et al.: A mellkasi aorta tompa sérülése - kezelési taktika, eredmények. Magyar Sebészet, 2015, 68(4): 155-166. DOI: 10.1556/1046.68.2015.4.1.

[5] Sándor P.: Treatment of the septic complication in the chest cavity: Vivano Spectrum, $2016 / 2$.

[6] Pellek S.: Surgical procedure protocol in septic chest cavity complications, LINK for Wound Healing Congress, 2017 Sept. 18-19. Belfast, N. Ireland, Konferencia előadás

[7] Pellek S.: Negatív nyomásterápia lehetőségei és szerepe a modern sebkezelésben, A Magyar Sebész Társaság Fiatal Sebészek Szekciójának V. Kongresszusa, 2017. április 7-9. Balatonalmádi

[8] Szentkereszty, Pellek S., Tóth: Negative Pressure Wound Therapy Budapest, Negatív nyomásterápiával a Sebgyógyulásért Egyesület, 2019.

[9] Szentkereszty, Pellek S., Tóth: Elméleti ismeretek és gyakorlati alkalmazás Negatív nyomásterápia, Biatorbágy, Negatív nyomásterápiával a Sebgyógyulásért Egyesület, 2017.
[10] Pellek S.: Treatment of chest cavity suppurations with NPWT following trauma and in some rare clinical cases, In: Szentkereszty, Pellek S., Tóth: Negative Pressure Wound Therapy, Budapest, Negatív nyomásterápiával a Sebgyógyulásért Egyesület, 2019, 121-126.

[11] Pellek S.: Mellüri gennyedések kezelése NPWT-vel, traumát követően és néhány ritka klinikai esetben, In: Szentkereszty, Pellek S. Tóth : Elméleti ismeretek és gyakorlati alkalmazás - Negatív nyomásterápia, Biatorbágy, Negatív nyomásterápiával a Sebgyógyulásért Egyesület, 2017, 121-126.

[12] Pellek S.: Szeptikus mellüregi folyamat kezelési stratégiája VIVANO NPWT módszerrel, Magyar Katonai- Katasztrófa Orvostani Társaság XIX. Tudományos Konferenciája. A Magyar Hadtudományi Társaság, Katasztrófa- és Védelem Egészségügyi Szakosztályával és a Negatív nyomásterápiával, a Sebgyógyulásért Egyesülettel közösen szervezett konferencia, 2016, november 16.

[13] Görög, Pellek S.: Az empysema korszerü NPWT kezelése. Magyar Traumatológus Társaság Kongresszusa, 2018. 
[14] Pellek S.: Negatív nyomásterápia a mellkassebészetben. Szakmai video, innovatív technológia bemutatása a hadműveleti tapasztalatok alapján https://www.youtube.com/ watch? $\mathrm{v}=\mathrm{ftEAE} 42 \mathrm{Qmuw}$

[15] Pellek S.: Mobil egészségügyi intézmény telepítése hadmüveleti területen. (Az afganisztáni, ISAF egészségügyi intézményeiben végzett többnemzetiségű egészségügyi ellátásról szerzett tapasztaltok alapján). Hadmérnök, 2009, 4(2): 157-165.

[16] Fekete A.: Modern sebkezelési eljárások alkalmazása minősített helyzetekben. Doktori (PhD) értekezés, Nemzeti Közszolgálati Egyetem, DOI: 10.17625/NKE.2014.034

[17] Várhelyi L.: Robbanásos sérülések sebészi ellátásának kérdései: Doktori $(\mathrm{PhD})$ értekezés. Zrinyi Miklós Nemzetvédelmi Egyetem, 2010.

[18] Záborszky Z.: Szemléletváltozás a hasi sérültek diagnosztikájában és terápiás megítélésében rendkívüli körülmények között és minősített helyzetben. Doktori (PhD) értekezés, Zrinyi Miklós Nemzetvédelmi Egyetem, 2010.

[19] Rashed Aref: A mikrocirkuláció szerepe a post-sternotomiás mediastinitis megelőzésében és kezelésében, PhD értekezés, Pécsi Tudományegyetem Általános Orvostudományi Kar, Klinikai Orvostudományok, Doktori Iskola, Pécs, 2018.

[20] Apelqvist, J. et al.: EWMA Document: Negative Pressure Wound Therapy. J. Wound Care., 2017, 26 (Sup.3): S1-S154. DOI: 0.12968/ jowc.2017.26.Sup3.S1.

[21] Reza Mafi et al.: The evidence-based principles of negative pressure wound therapy
(NPWT) dressing applications. A review of the literature, Int. J. Infect. Control, 2014, 10: 12. DOI: 10.3396/IJIC.v10i2.011.14

[22] Irodalmi szemle. Tábori egészségügy és hadisebészet. Rovatvezető: Sereghy E. Orvosi Hetilap. 1941, 49. szám. 632.

DOI: $10.1556 / 650.1941 .12 .06$

\section{Col. S. Pellek MDMC, PhD}

\section{Military medical experiences in the service of innovation}

The continuous development of medicine divies and smaller specialities appear due to the increase in knowledge in each field. Military medicine has also a significant added value in development. Experience, innovation and their application in the field of operations can provide a boost to modern medicine in peace-time. In this article, the autor demonstrates his experiences in Afghanistan, in the treatment of septic thoracic complications and on the peace-time application of the results.

Key-words: military medicine, innovation, thorax, Negativ Pressure Wound Treatment (NPWT)

Dr. Pellek Sándor o. ezds., PhD 1134 Budapest, Róbert Károly krt. 44. 